\title{
Cell Wall-associated 1,4- $\beta$-D-Xylanase in Cryptococcus albidus var. aerius: in situ Characterization of the Activity
}

\author{
By VICENTE NOTARIO,* TOMAS G. VILLA† AND \\ JULIO R. VILLANUEVA \\ Department of Microbiology, Faculty of Sciences and Institute of Biochemical \\ Microbiology, C.S.I.C., University of Salamanca, Salamanca, Spain
}

(Received 22 November 1978; revised 23 February 1979)

1,4- $\beta$-D-Xylanase (1,4- $\beta$-D-xylan xylanohydrolase; EC 3.2.1.8) has been detected in both cell-free extracts and culture fluids of the yeast Cryptococcus albidus var. aerius grown on glucose as the only carbon source. Mild acid treatment of whole cells proved that the enzyme was extracellularly located. The activity remained almost completely linked to the wall after cell breakage, only being liberated in the presence of salt at high concentration. After release, the enzyme became very unstable and so has been characterized in situ in 'permeabilized' cells. The maximum production took place at the beginning of the exponential growth phase. The optimum $\mathrm{pH}$ and temperature for activity were 5.0 and $40{ }^{\circ} \mathrm{C}$, respectively. The enzyme degraded xylan and xylo-oligosides by an endo-splitting mechanism giving xylobiose, xylotriose and xylose as the main end-products. Activation energy and kinetic constants for xylan degradation were determined. Several metal ions such as $\mathrm{Ag}^{+}$and $\mathrm{Hg}^{2+}$ inhibited the enzyme. The possible function of this endo-xylanase in Cr. albidus var. aerius is discussed.

\section{INTRODUCTION}

Cryptococci constitute a group of micro-organisms which differ from typical yeasts in a number of characteristics. Some of these concern the composition and structure of their cell envelopes. Bacon et al. (1968) described the occurrence of 1,3- $\alpha$-glucan as a component of cryptococcal walls, and unusual sugars such as xylose, galactose and glucuronic acid have been isolated from extracellular polysaccharides (Golubev \& Vdovina, 1974) and walls (Notario, 1977) of cryptococci. However, little attention has been paid so far to the lytic enzymes able to break down 1,3- $\alpha$-glucans and, especially, xylose-containing polysaccharides in these yeasts. Only recently, Notario et al. (1976a) and Meyer \& Phaff (1977) demonstrated the presence of $\beta$-xylosidases and 1,3- $\alpha$-glucanases in several cryptococci.

Although Biely et al. (1978) described the growth of certain yeasts on xylan and hemicelluloses, the existence of endo-xylanases among yeasts has been described (and then only briefly) in very few papers (e.g. Stevens \& Payne, 1977). The present paper describes the detection, location and partial characterization of endo-xylanase activity in the yeast Cryptococcus albidus var. aerius.

\section{METHODS}

Organism and culture conditions. Cryptococcus albidus var. aerius (CECT 1280), obtained from the Spanish Type Culture Collection (Salamanca, Spain), was grown as described by Notario et al. (1976b).

Substrates and chemicals. Commercial larchwood xylan (Sigma) was purified by the procedure of Aspinall \& McKay (1958) as modified by Stevens \& Payne (1977). A fraction containing about $98.5 \%$ xylose and

* Present address: Department of Biochemistry, University of Cambridge, Cambridge CB2 1QW.

$\dagger$ To whom reprint requests should be addressed. 
$1.5 \%$ glucose was used for the enzyme assays. Xylan was partially hydrolysed as described by Wolfrom \& Franks (1965) and different xylo-oligosides were separated and characterized according to Whistler \& Tu (1952). $p$-Nitrophenyl- and methyl- $\beta$-D-glucopyranosides were purchased from Koch-Light. Phenylmethylsulphonyl fluoride (PMSF) was from Sigma, and celluloses (Whatman CC-31, CM-52 and DE-52) were from BDH.

Enzyme preparation. Crude enzyme extracts were prepared from culture fluids and cell-free extracts of exponentially growing cells were obtained as described by Villa et al. (1976) and Notario et al. (1976b), respectively. In some experiments $0.02 \mathrm{M}$-PMSF was present throughout the enzyme preparation.

Enzyme assays. Standard assays contained $0.2 \mathrm{ml}$ enzyme preparation plus $0.8 \mathrm{ml}$ substrate $(0.15 \%$, $\mathrm{w} / \mathrm{v}$, solutions in $50 \mathrm{~mm}$-sodium acetate buffer, $\mathrm{pH} \mathrm{5.5)}$ and were incubated at $37^{\circ} \mathrm{C}$ for $5 \mathrm{~min}$. Assays were stopped by adding $0.3 \mathrm{M}-\mathrm{ZnSO}_{4}(1 \mathrm{ml})$ and $0.3 \mathrm{M}-\mathrm{Ba}(\mathrm{OH})_{2}$ or by heating at $100^{\circ} \mathrm{C}$ for $5 \mathrm{~min}$ followed by centrifuging. The reaction products were determined in the supernatant fractions.

Enzyme activity was followed by measuring the release of reducing sugars and xylose from the substrate. Reducing power was determined by Nelson's method (1944) or by that of Park \& Johnson (1949). Xylose was measured as described by Dische \& Borenfreund (1957). Results were always referred to xylose as standard. One unit of activity was defined as $1 \mathrm{nmol}$ xylose or equivalent reducing power released from each substrate $\min ^{-1}$.

Xylanase assays in situ. The enzyme activity was determined in cells 'permeabilized' according to Serrano et al. (1973). Culture samples were centrifuged, washed twice with water and resuspended in water (final vol. $2 \mathrm{ml})$. The final cell concentration was always adjusted to $6 \times 10^{6} \mathrm{cells} \mathrm{ml^{-1 }}$. A mixture $(0.2 \mathrm{ml})$ of toluene/ ethanol $(1: 1$, by vol.) was added and the suspension was vigorously shaken for $5 \mathrm{~min}$. The cells were then repeatedly washed with water and 50 mM-sodium acetate buffer, $\mathrm{pH} 5 \cdot 5$, and resuspended in similar buffer (final vol. $1 \mathrm{ml}$ ). The resulting cell suspension was used as the enzyme preparation for standard assays. Controls without exogenous substrate were run in every case to avoid any possible interference due to autolytic reactions.

Enzyme characterization. Assays to determine the optimum $\mathrm{pH}$ were done using different buffers within the $\mathrm{pH}$ range from 2.5 to 10.5 . Each assay contained $0.2 \mathrm{ml}$ permeabilized cells, $0.4 \mathrm{ml}$ xylan $(0.15 \% \mathrm{w} / \mathrm{v}$, in water) and $0.4 \mathrm{ml}$ of the appropriate buffer. The influence of temperature was estimated between 5 and $80^{\circ} \mathrm{C}$. Enzyme inactivation by $\mathrm{pH}$ or temperature was determined from assays carried out under standard conditions but with enzyme preparations preincubated at the different $\mathrm{pH}$ values or temperatures for $10 \mathrm{~min}$.

Inhibition experiments with metal ions were carried out by adding $0.2 \mathrm{ml}$ of enzyme preparation to a mixture of $0.2 \mathrm{ml}$ of freshly prepared inhibitor solution (up to $0.25 \mathrm{~mm}$ ) and $0.6 \mathrm{ml}$ of buffered substrate.

Control tests in which permeabilized cells were treated, in the absence of substrate, at different $\mathrm{pH}$ values or temperatures or incubated with metal ions were always performed.

Paper chromatography. Descending paper chromatography was used to check the purity of xylan and xylo-oligosides and to characterize the products of the enzymic reactions. Samples were chromatographed on Whatman no. 1 paper for $24 \mathrm{~h}$ with ethyl acetate/pyridine/water (8:2:1, by vol.) as solvent. Glucose, xylo-oligosides and xylose were used as references. Spots were developed with aniline phthalate (Partridge, 1949).

Miscellaneous determinations. Culture growth was determined by the increase in absorbance at $600 \mathrm{~nm}$ throughout incubation, or by determining the total cell number using a Thoma haemocytometer. Total protein was determined by Lowry's method and free glucose by that of Keston (1956). Enzyme location was studied as described by Arnold (1972). $\beta$-Glucanase and $\beta$-xylosidase were assayed as described by Notario et al. $(1976 a, b)$.

\section{RESULTS AND DISCUSSION}

\section{Xylanase activity in crude enzyme preparations}

Enzyme extracts were incubated in the presence of xylan for different times (up to $3 \mathrm{~h}$ ). With longer incubations lower activities were found, and after $1 \mathrm{~h}$ only $5 \%$ and $2 \%$ (referred to 2.5 min tests) of the activity was recovered from cell-free extracts and culture fluids, respectively (Fig. 1 a). Attempts to repeat the assays with the same preparations were completely unsuccessful because no xylanase activity could be detected. Extraction conditions were strictly controlled, but similar results were obtained whenever crude enzyme preparations were used. Attempts to stabilize the enzyme by addition of proteins (i.e. bovine serum albumin) were unsuccessful. The possible presence of proteases that could inactivate the enzyme was considered, but the presence of the protease inhibitor PMSF throughout the whole enzyme extraction and assay processes had no effect. 


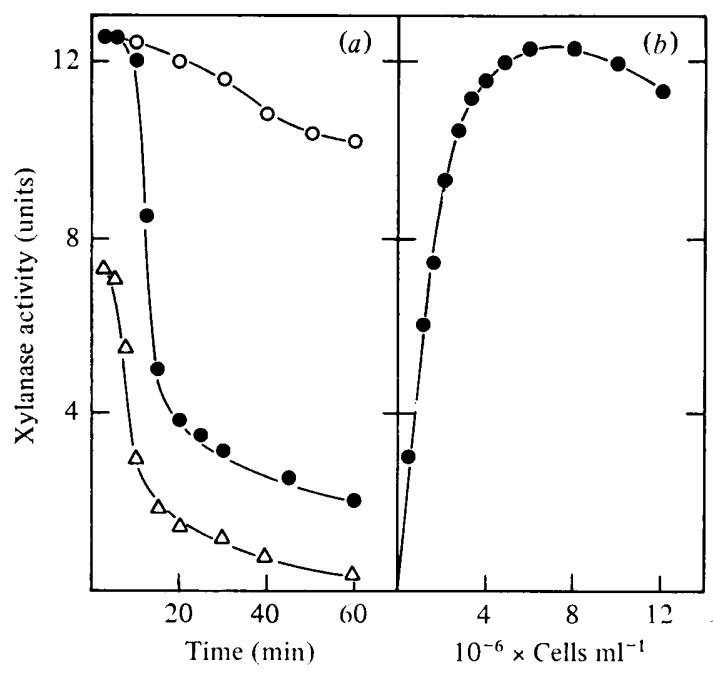

Fig. 1. Effect of incubation time (a) and cell concentration in the assays $(b)$ on xylanase activity. Reactions were carried out under conditions described in the text with cell-free extracts $(\triangle)$, permeabilized cells $(O)$ and purified walls $(O)$ as enzyme sources.

\section{Cellular location of the xylanase activity}

The pellet obtained after centrifuging for $40 \mathrm{~min}$ at $40000 \mathrm{~g}$ (containing some whole cells, wall debris, membranes etc.) had higher activity than the crude extract. When associated with cell structures the enzyme was apparently much more stable (only $18 \%$ loss of activity after $1 \mathrm{~h}$ incubation). Experiments were therefore carried out to establish its precise cellular location. As shown in Table 1, xylanase activity was completely lost after treatment of exponentially growing cells with $0 \cdot 1 \mathrm{M}-\mathrm{HCl}$, while neither cell viability nor $\alpha$-glucosidase, a typical intracytoplasmic enzyme in Cr. albidus var. aerius (Notario et al., 1976a), was affected. This finding suggested that xylanase was mainly located within the periplasmic space. Such a periplasmic location has been described for other yeast glycoside-hydrolases (Villa et al., 1975).

\section{Wall-associated xylanase activity}

Walls were prepared and purified as described by Fleet \& Phaff (1974) and checked for xylanase activity using suspension of purified walls as the source of enzyme. It was found that about $97 \%$ of the total activity was associated with the walls and in that condition appeared much more stable than in crude extracts (Fig. $1 a$ ). The linkage between xylanase and walls appeared rather weak since all the activity could be removed from the walls simply by washing with $2 \mathrm{M}-\mathrm{NaCl}$. The solubilized enzyme was as unstable as that in crude extracts.

\section{Xylanase activity in permeabilized cells}

Wall isolation and purification is often time-consuming, and is especially so in $C r$. albidus var. aerius (Notario et al., 1976b). Moreover, preliminary evidence suggested that certain wall materials were always lost during purification. Permeabilized cells were thought to reflect more closely the situation in vivo, and no marked difference in enzyme stability, with respect to that associated with purified walls, was found after short incubation periods ( 2.5 to $5 \mathrm{~min}$ ). No xylose or reducing sugars were released when permeabilized cells were incubated for similar periods at $37^{\circ} \mathrm{C}$ in the absence of exogenous substrate. For these reasons, $5 \mathrm{~min}$ assays with permeabilized cells as the enzyme source were adopted for subsequent experiments. 
Table 1. Cellular location of endo-1,4- $\beta$-D-xylanase from
Cryptococcus albidus var. aerius

Xylanase activity is expressed as described in Methods. $\alpha$-Glucosidase is expressed as $\mu$ mol $p$-nitrophenol liberated from $0.25 \%(\mathrm{w} / \mathrm{v})$ p-nitrophenyl- $\alpha$-D-glucoside $\min ^{-1} \mathrm{ml}^{-1}$ at $37^{\circ} \mathrm{C}$. Viable cells were counted under the microscope after $3 \mathrm{~min}$ suspension in $0.01 \%(\mathrm{w} / \mathrm{v})$ methylene blue prepared in 50 mm-sodium acetate buffer, $\mathrm{pH} 5 \cdot 5$.

\begin{tabular}{lcc}
\multicolumn{2}{c}{ Treatment } \\
\cline { 2 - 3 } Percentage of viable cells & 99 & $0 \cdot 1 \mathrm{M}-\mathrm{HCl}, \mathbf{1 ~ h}$ \\
$\alpha$-Glucosidase activity & $2 \cdot 49$ & $97 \cdot 5$ \\
Xylanase activity & $12 \cdot 85$ & $2 \cdot 45$ \\
trace
\end{tabular}

\section{Production of xylanase in synchronous cultures}

Unlike most fungal xylanases, which are only detected when micro-organisms are grown on xylan or its derivatives (King \& Fuller, 1968), Cr. albidus var. aerius synthesized the enzyme when grown on glucose as carbon source. The enzyme appeared to be constitutive and higher activities were not obtained when xylan $(1 \%, \mathrm{w} / \mathrm{v}$ ) or xylose (up to $10 \%, \mathrm{w} / \mathrm{v}$ ) were used as carbon sources. The maximum rise in xylanase activity took place at the beginning of the exponential phase of growth ( $12 \mathrm{~h}$ cultures), and another peak of activity was detected in the early stationary phase ( $36 \mathrm{~h}$ growth). This second peak coincided with those described for 1,3- and 1,6- $\beta$-D-glucanases in the same yeast (Notario et al., 1976b). Only low levels of activity were found at other stages of growth (Fig. 2).

\section{Enzyme characterization}

Effect of incubation time. As previously indicated, enzyme activity declined progressively when assays were developed for periods up to $3 \mathrm{~h}$. When permeabilized cells were used as the source of enzyme, only $14.5 \%$ of the activity was recovered after $1 \mathrm{~h}$ incubation under standard conditions (Fig. 1a).

Effect of cell concentration. Activity increased linearly when the concentration of per-

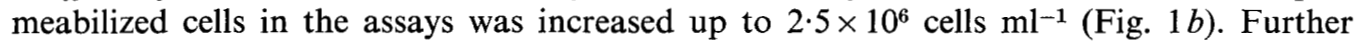
increases in the amount of cells did not give significantly higher levels of activity (between $3 \times 10^{6}$ and $7 \times 10^{6}$ cells $\mathrm{ml}^{-1}$ ) and even had an inhibitory effect (above $7 \cdot 5 \times 10^{6}$ cells $^{-1}$ ).

Effect of $p H$. The highest enzyme activity was obtained at $\mathrm{pH} 5 \cdot 0$. This was also considered to be the optimum $\mathrm{pH}$ since samples of permeabilized cells that had been maintained at $\mathrm{pH} 5.0$ for $10 \mathrm{~min}$ before being assayed showed almost full activity. This optimum $\mathrm{pH}$ value is in the range reported for other lytic enzymes (Villa et al., 1975). However, this enzyme had a narrower $\mathrm{pH}$-dependence since slight deviations from the optimum value caused significant loss of activity (about $25 \%$ loss at $\mathrm{pH} 4.5$ or $5 \cdot 5$ ).

Effect of temperature. At the optimum $\mathrm{pH}$ the maximum xylanase activity was obtained at $50{ }^{\circ} \mathrm{C}$. However, $5 \%$ loss of activity was detected after $10 \mathrm{~min}$ preincubation under these conditions, whereas practically no inactivation occurred at $40^{\circ} \mathrm{C}$. The activation energy for the enzymic hydrolysis of xylan was estimated to be $15925 \pm 1480 \mathrm{~J} \mathrm{~mol}^{-1}$.

Effect of substrate concentration. The enzyme activity was determined at $\mathrm{pH} 5.0$ and $37{ }^{\circ} \mathrm{C}$ for a series of increasing concentrations of xylan. From reciprocal plots, the apparent Michaelis-Menten constant $\left(K_{\mathrm{m}}\right)$ was estimated to be $0 \cdot 121 \mathrm{mM}$. This $K_{\mathrm{m}}$ value is expressed on a molar basis assuming a molecular weight of 16200 for the purified xylan, corresponding to a DP value of 123 as determined by the enzymic procedure described by Sturgeon (1973).

Inhibition by metal ions. $\mathrm{Zn}^{2+}, \mathrm{Mn}^{2+}, \mathrm{Pb}^{2+}, \mathrm{Hg}^{2+}$ and $\mathrm{Ag}^{+}$(as chlorides) were tested for any inhibitory effect on xylanase activity. A continuous decrease in activity was caused by 


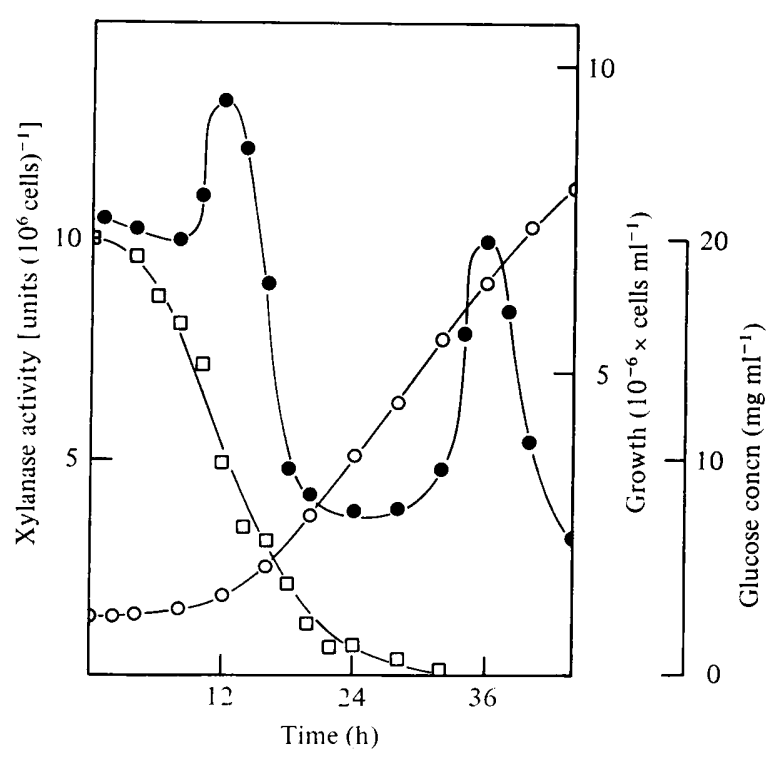

Fig. 2. Production of endo-1,4- $\beta$-D-xylanase (O) by Cryptococcus albidus var, aerius growing in asynchronous cultures. Culture growth $(\bigcirc)$; free glucose in the medium ( $\square$ ).

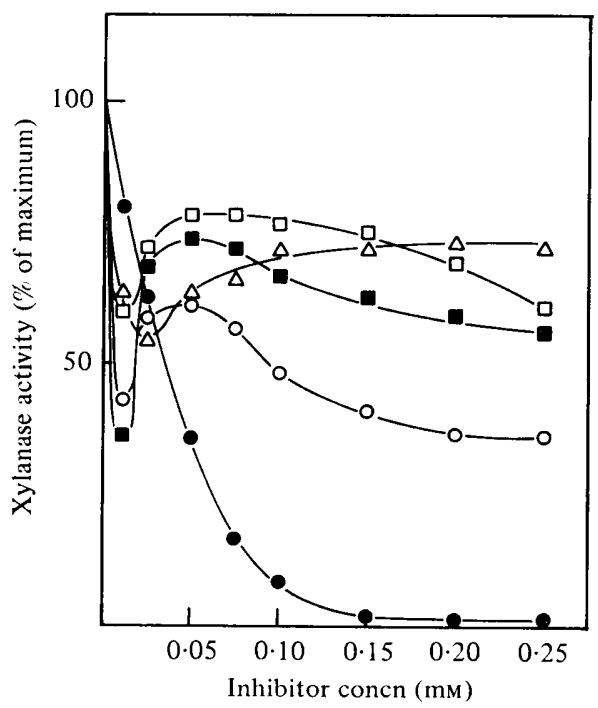

Fig. 3. Inhibitory effect promoted by metal ions on xylan degradation by endo-1,4- $\beta$-D-xylanase from Cryptococcus albidus var. aerius: $\mathrm{Ag}^{+}(\mathrm{O}), \mathrm{Hg}^{2+}(\bigcirc), \mathrm{Pb}^{2+}(\square), \mathrm{Mn}^{2+}(\square), \mathrm{Zn}^{2+}(\triangle)$.

increasing the concentration of $\mathrm{Ag}^{+}$, total inhibition being observed at concentrations higher than $0.15 \mathrm{~mm}$. At very low concentrations $(0.01 \mathrm{mM})$ all the divalent cations induced a rapid decrease of activity to about 40 to $60 \%$ of that in control experiments. However, less inhibition occurred at higher ionic concentrations, resulting in rather peculiar inhibition curves (Fig. 3). Inverse plots were non-linear and evaluation of $K_{1}$ values by extrapolation was not possible. There is no clear explanation for such a phenomenon. It is possible that these ions at low ionic concentrations were able to promote direct inhibition of the enzyme activity, whereas at higher concentrations, despite some inhibition, they could provide more 
Table 2. Total reducing sugars released by the action of xylanase alone or with other enzymes on whole cells, purified walls and wall fractions isolated from Cryptococcus albidus var. aerius

Walls purified from cells grown for $36 \mathrm{~h}$ were used both as enzyme source and as substrate. Those to be used as substrate were heated for $10 \mathrm{~min}$ at $100^{\circ} \mathrm{C}$ to inactivate any endogenous lytic enzyme. Those to be used as the enzyme source were treated with toluene (as whole cells, see Methods). Toluene-treated walls contained similar amounts of xylanase to untreated walls but did not show detectable levels of $\beta$-xylosidase or glucanases unless incubations were maintained for very long periods $(30 \mathrm{~h}$ at least). Whole cells and two xylose-containing fractions (wall fractions 1 and 2 , containing 4 and $5 \%$ xylose, respectively), prepared from $\mathrm{Cr}$. albidus var. aerius walls by a modification of Adam's (1965) procedure, were also used as substrate. Endo- and exo-1,3- $\beta$-D-glucanases and $\beta$-xylosidase, purified from cell-free extracts of $C r$. albidus var. aerius (Notario, 1977), were also used. The final concentration of these enzymes in the assay reactions was adjusted to 125 units (defined by their activity on laminarin or $p$-nitrophenyl- $\beta$-D-xylopyranoside, as in Methods). Assay mixtures contained $0.5 \mathrm{ml}$ enzyme $(2.5 \mathrm{mg}$ dry wt permeabilized walls, or purified lytic enzymes, in buffer) plus $0.5 \mathrm{ml}$ of buffered substrate and were incubated under standard conditions for 2 or $5 \mathrm{~h}$. Reactions were stopped by centrifuging and reducing sugars were determined in the supernatants. When enzyme mixtures were used the procedure included a 30 min pretreatment with xylanase alone before addition of the other enzymes.

\begin{tabular}{|c|c|c|c|c|c|c|c|c|}
\hline \multirow[b]{3}{*}{ Enzyme } & \multicolumn{8}{|c|}{ Reducing sugars released $\left[\mu \mathrm{g}(\mathrm{mg} \text { dry wt substrate })^{-1}\right]$} \\
\hline & Wh & cells & Purif & walls & Wall & tion 1 & Wall & ction 2 \\
\hline & $2 \mathrm{~h}$ & $5 \mathrm{~h}$ & $2 \mathrm{~h}$ & $5 \mathrm{~h}$ & $2 \mathrm{~h}$ & $5 \mathrm{~h}$ & $2 \mathrm{~h}$ & $5 \mathrm{~h}$ \\
\hline Endo-1,3- $\beta$-D-glucanase & 26 & 165 & 32 & 205 & 22 & 155 & 12 & 120 \\
\hline Exo-1,3- $\beta$-D-glucanase & 68 & 350 & 83 & 407 & 75 & 407 & 15 & 237 \\
\hline$\beta$-Xylosidase & 6 & 105 & 28 & 140 & 34 & 160 & 56 & 215 \\
\hline Xylanase & 4 & 60 & 16 & 88 & 18 & 95 & 23 & 110 \\
\hline Xylanase + endo-1,3- $\beta$-D-glucanase & 35 & 208 & 55 & 296 & 38 & 265 & 40 & 307 \\
\hline Xylanase + exo-1,3- $\beta$-D-glucanase & 206 & 604 & 307 & 892 & 289 & 835 & 104 & 398 \\
\hline Xylanase $+\beta$-xylosidase & 25 & 256 & 78 & 461 & 176 & 606 & 86 & 419 \\
\hline
\end{tabular}

favourable conditions for the stability of the enzyme-substrate complexes or allow greater accessibility of the enzyme to the substrate. This possibility would be in agreement with that proposed by Villa et al. (1978) to explain the effect of $\mathrm{NaCl}$ on certain $\beta$-glucanases.

When applied to $\mathrm{Hg}^{2+}$, this explanation would be consistent with the proposed role of $-\mathrm{SH}$ groups in controlling the activity of yeast wall lytic enzymes (Notario et al., 1976c). However, the fact that $\mathrm{Hg}^{2+}$ did not inhibit the activity completely, as it does with other lytic enzymes (Notario et al., 1976b, c; Villa et al., 1978), suggests either that -SH groups are not essential for the catalytic activity of the enzyme, or that in situ other -SH groups possibly involved in maintaining the enzyme structure might be less susceptible than in solubilized enzymes.

Substrate specificity and pattern of hydrolysis. Only xylan, xylo-oligosides and cellulose were used for these experiments. Cells grown for $36 \mathrm{~h}$ (showing low $\beta$-xylosidase but high xylanase activities) were chosen as the source of enzyme to avoid, as far as possible, the interference by other lytic enzymes present in the permeabilized cells. Toda et al. (1970) showed that certain xylanases were in fact cellulases. No activity against crystalline or pre-swollen celluloses was found, suggesting that the enzyme was a true xylanase. The enzyme was active on xylan and xylo-oligosides, but the degree of activity decreased in parallel with the chain length of the substrate and no xylobiase activity could be attributed to the xylanase.

Chromatographic analysis of supernatants of reaction mixtures showed that xylotetraose, xylotriose and xylobiose (after $30 \mathrm{~min}$ assays), xylotriose, xylobiose and traces of xylotetraose (after $2 \mathrm{~h}$ ) and xylotriose, xylobiose and xylose (after $5 \mathrm{~h}$ ) were the main products of the enzymic reactions. Traces of xylose were detected early in the tests but they appeared to be due to $\beta$-xylosidase activity. Similar results were obtained when purified walls (almost 
free of $\beta$-xylosidase and glucanases) were used as the source of enzyme. These results suggested that the xylanase was an endo-splitting enzyme with a hydrolytic pattern similar to that described by Gorbacheva \& Rodionova (1977) for an enzyme from Aspergillus niger able to break down xylans at random giving xylobiose $>$ xylotriose $>$ xylose as end-products.

\section{Xylanase functions: action on whole cells and isolated walls}

Xylanase alone or in combination with other lytic enzymes promoted significant release of reducing sugars from whole cells, purified walls and two xylose-containing wall fractions (Table 2). As expected from their respective patterns of hydrolysis, xylanase pretreatment caused a significant increase in $\beta$-xylosidase activity. In the case of $\beta$-glucanases a synergistic action was restricted to exo-enzymes. Notario (1977) suggested that the wall structure in this yeast would be strengthened by xylo-oligosidic bridges between glucan and mannan, and that their degradation might be crucial in morphogenetic events involving localized partial hydrolysis of the wall. The high instability of the enzyme studied, its occasional production at the beginning of active growth, and its co-operativity with other enzymes of the same yeast seem to support this hypothesis. However, the fact that neither complete wall dissolution nor protoplast formation occurred (even when all the enzymes were acting together) would indicate that other plasticizing factor(s) are also involved in wall dynamics in Cr. albidus var. aerius. On other hand, the production of xylanase by stationary phase cells could be related to a metabolic function such as the modification of wall materials or the digestion of external glycoproteins secreted into the culture medium by the cells.

This work was done with the support of the Ministerio de Educación of Spain through fellowships to V. Notario and T. G. Villa. The authors wish to thank Dr D. Kerridge for correcting the manuscript.

\section{REFERENCES}

Adams, G. A. (1965). Arabinoglucuronoxylan, arabinoxylan, and xylan; purification using a copper complex and purification by fractional precipitation of acetates. Methods in Carbohydrate Chemistry 5, 170-175.

ARNold, W. N. (1972). The structure of the yeast cell wall. Solubilization of a marker enzyme, $\beta$-fructofuranosidase, by the autolytic enzyme system. Journal of Biological Chemistry 247, 1161-1169.

Aspinall, G. O. \& McKay, J. E. (1958). The hemicelluloses of European larch (Larix decidua). Part I. The constitution of a xylan. Journal of the Chemical Society, 1059-1166.

Bacon, J. S. D., Jones, D., FARmer, V. C. \& Webley, D. M. (1968). The occurrence of $\alpha-(1-3)$ glucan in Cryptococcus, Schizosaccharomyces and Polyporus species, and its hydrolysis by a Streptomyces culture filtrate lysing cell walls of Cryptococcus. Biochimica et biophysica acta 158, 313-315.

Biely, P., Kratky, Z., Kockova-KratochVilova, A. \& BAUER, S. (1978). Xylan-degrading activity in yeasts: growth on xylose, xylan and hemicelluloses. Folia microbiologica 23, 366-371.

Dische, Z. \& Borenfreund, E. (1957). A new color reaction for the determination of aldopentoses in presence of other saccharides. Biochimica et biophysica acta 23, 639-642.

Fleet, G. H. \& PhafF, H. J. (1974). Glucanases in Schizosaccharomyces. Isolation and properties of the cell wall-associated $\beta-1,3$-glucanase. Journal of Biological Chemistry 249, 1717-1728.
Golubev, W. I. \& Vdovina, N. V. (1974). Monosaccharide composition of extracellular polysaccharides of some Cryptococcus species. Microbiologiya 43, 154-156.

Gorbacheva, I. V. \& Rodionova, N. A. (1977). Studies on xylan-degrading enzymes. II. Action pattern of endo-1,4- $\beta$-xylanase from Aspergillus niger str. 14 on xylan and xylooligosaccharides. Biochimica et biophysica acta 484, 94-102.

Keston, A. S. (1956). Specific colorimetric enzymatic reagents for glucose. 129th Meeting of the American Chemical Society, abstract 31c.

King, N. J. \& Fuller, D. B. (1968). The xylanase system of Coniophora cerebella. Biochemical Journal 108, 571-576.

Meyer, M. T. \& Phaff, H. J. (1977). Survey of $\alpha-(1 \rightarrow 3)$-glucanase activity among yeasts. Journal of Bacteriology 131, 702-706.

Nelson, N. (1944). A photometric adaptation of the Somogyi method for the determination of glucose. Journal of Biological Chemistry 153, 375-380.

NotARIo, V. (1977). Crecimiento y morfogénesis en levaduras. Estudio de $\beta$-glucanasas y otros enzimas relacionados en Cryptococcus albidus var. aerius. Ph.D. Thesis, University of Salamanca, Spain. Notario, V., Villa, T. G. \& VillanueVa, J. R. (1976a). $\beta$-Xylosidases in the yeast Cryptococcus albidus var. aerius. Canadian Journal of Microbiology 22, 312-315.

Notario, V., Villa, T. G., Benitez, T. \& VillaNUEVA, J. R. $(1976 b) . \beta$-Glucanases in the yeast Cryptococcus albidus var. aerius. Production and 
separation of $\beta$-glucanases in asynchronous cultures. Canadian Journal of Microbiology 22, 261-268.

Notario, V., Villa, T. G. \& Villanueva, J. R. $(1976 c)$. Purification of an exo $\beta$-D-glucanase from cell-free extracts of Candida utilis. Biochemical Journal 159, 555-562.

Park, J. T. \& Johnson, M. J. (1949). A submicrodetermination of glucose. Journal of Biological Chemistry 181, 149-151.

PARTRIDGe, S. M. (1949). Aniline hydrogen phthalate as a spraying reagent for chromatography of sugars. Nature, London 164, 443.

Serrano, R., Gancedo, J. M. \& Gancedo, C. (1973). Assay of yeast enzymes in situ. A potential tool in regulation studies. European Journal of Biochemistry 34, 479-482.

Stevens, B. J. H. \& Payne, J. (1977). Cellulase and xylanase production by yeasts of the genus Trichosporon. Journal of General Microbiology 100, 381-393.

STURGEON, R. J. (1973). Determination of the degree of polymerization of xylans. Carbohydrate Research 30, 175-178.
Toda, S., Suzuki, H. \& Nisizawa, K. (1970). Isolation of cellulase components with xylanase activity. Hakko kogaku zasshi 48, 580-586.

Villa, T. G., Notario, V. \& Villanueva, J. R. (1975). $\beta$-Glucanases of the yeast Pichia polymorpha. Archives of Microbiology 104, 201-206.

Villa, T. G., Notario, V., Benitez, T. \& VillaNueva, J. R. (1976). Purification of an exo-1,3- $\beta$ glucanase from Candida utilis. Canadian Journal of Biochemistry 54, 927-934.

Villa, T. G., Lachance, M. A. \& Phaff, H. J. (1978). $\beta$-Glucanases of the yeast Kluyveromyces phaseolosporus: partial purification and characterization. Experimental Mycology 2, 12-25.

WHISTLER, R. L. \& Tu, C. C. (1952). Isolation and properties of a series of crystalline oligosaccharides from xylan. Journal of the American Chemical Society 74, 3609-3612.

Wolfrom, M. L. \& Franks, N. E. (1965). Preparation of polymer-homologous oligosaccharides; xyloglycoses from xylan. Methods in Carbohydrate Chemistry 5, 276-280. 